\title{
Exposure to a sublethal concentration of imidacloprid and the side effects on target and nontarget organs of Apis mellifera (Hymenoptera, Apidae)
}

\author{
Aline Fernanda Catae ${ }^{1} \cdot$ Thaisa Cristina Roat $^{1} \cdot$ Marcel Pratavieira $^{1} \cdot$ \\ Anally Ribeiro da Silva Menegasso ${ }^{1} \cdot$ Mario Sergio Palma $^{1} \cdot$ Osmar Malaspina $^{1}$
}

Accepted: 25 October 2017 / Published online: 10 November 2017

(C) Springer Science+Business Media, LLC 2017

\begin{abstract}
The use of insecticides has become increasingly frequent, and studies indicate that these compounds are involved in the intoxication of bees. Imidacloprid is a widely used neonicotinoid; thus, we have highlighted the importance of assessing its oral toxicity to Africanized bees and used transmission electron microscopy to investigate the sublethal effects in the brain, the target organ, and the midgut, responsible for the digestion/absorption of food. In addition, the distribution of proteins involved in important biological processes in the brain were evaluated on the 1st day of exposure by MALDI-imaging analysis. Bioassays were performed to determine the Median Lethal Concentration $\left(\mathrm{LC}_{50}\right)$ of imidacloprid to bees, and the value obtained was $1.4651 \mathrm{ng}$ imidacloprid/ $\mu \mathrm{L}$ diet. Based on this result, the sublethal concentration to be administered at 1,4 and 8 days was established as a hundredth $(1 / 100)$ of the $\mathrm{LC}_{50}$. The results obtained from the ultrastructural analysis showed alterations in the midgut cells of bees as nuclear and mitochondrial damage and an increase of vacuoles. The insecticide caused spacing among the Kenyon cells in the mushroom bodies, chromatin condensation and loss of mitochondrial cristae. The MALDI-imaging analysis showed an increase in the expression of such proteins as vascular endothelial growth factor receptor, amyloid protein precursor and protein kinase $\mathrm{C}$, which are related to oxygen supply, neuronal degeneration and memory/learning, and a decrease in the expression of the nicotinic acetylcholine receptor alpha 1 , which is fundamental to the synapses.
\end{abstract}

Aline Fernanda Catae

aline_catae@hotmail.com

1 Departamento de Biologia, Centro de Estudos de Insetos Sociais, UNESP - Univ. Estadual Paulista, campus de Rio Claro, Instituto de Biociências, Rio Claro, SP, Brazil
These alterations demonstrated that imidacloprid could compromise the viability of the midgut epithelium, as well as inhibiting important cognitive processes in individuals, and may be reflected in losses of the colony.

Keywords Neonicotinoid $\cdot$ Lethal concentration • Ultrastructure $\cdot$ Midgut $\cdot$ Brain $\cdot$ MALDI-imaging

\section{Introduction}

Hymenoptera is the most well-studied order of insects, being important pollinators of countless species of plants (Percival 1965; Amaral and Alves 1979; Crepet 1983; Lenzi et al. 2003). Because these bees use floral resources, especially nectar and pollen, as a source of food and energy, they are extremely important to the process of pollination of native and cultivated areas (Kearns and Inouye 1997; Nogueira-Neto 1997) and are considered the most effective floral visitors among the known pollinators (Michener 1954; Friedman and Shmida 1995; Griswold et al. 1995; Wilms et al. 1997).

It is estimated that $90 \%$ of fruit trees depend directly on the pollination carried out by these insects for their reproductive success (Tautz 2008). Of the plant species of worldwide agricultural interest, $73 \%$ are pollinated by bees, $19 \%$ by flies, $6.5 \%$ by bats, $5 \%$ by wasps, $5 \%$ by beetles, $4 \%$ by birds and $4 \%$ by butterflies and moths (FAO 2004).

However, bees are vulnerable to pesticides applied in agricultural crops for pest control. Bees' genomes feature a deficiency in the number of genes that encode enzymes capable of metabolizing such products compared to other insects (Claudianos et al. 2006). 
Among the most widely used insecticides today, the neonicotinoids stand out. Having a relatively large variety of applications and extended residual effects, these products represent useful tools in modern agriculture (Elbert et al. 2008). For example, since its introduction in the mid-1990s, the use of imidacloprid has increased considerably, and it is currently considered to be possibly the most-used insecticide in the control of agricultural pests and diseases (Freitas and Pinheiro 2010; Blacquière et al. 2012).

These insecticides act primarily on the nervous systems of insects, being agonists of acetylcholine receptors (Suchail et al. 2004). The insecticides bind to nicotinic acetylcholine receptors located on postsynaptic neurons of insects, acting primarily on the $\alpha$ subunits of the receptor (Buckingham et al. 1997; Suchail et al. 2004). In contrast to acetylcholine, which is hydrolyzed by acetylcholinesterase, this compound is not degraded immediately; therefore, nerve impulses are transmitted continuously and lead to hyperexcitation of the insect's nervous system (Gallo et al. 2002).

The nervous system of insects consists of a brain and a ventral nerve cord, being organized into central and peripheral nervous systems. The bee brain consists of three main regions: protocerebrum, deutocerebrum, and tritocerebrum. The mushroom bodies are located in the protocerebrum, being directly related to learning and memory (Daly et al. 1998). These bodies consist of numerous neurons (Kenyon cells) that can be differentiated into inner compact, noncompact and outer compact cells according to the amount of cytoplasm relative to the nucleus (Farris and Sinakevitch 2003; Fahrbach 2006).

Imidacloprid is an insecticide that has a systemic action in the plant, contaminating pollen and nectar (Bonmatin et al. 2015), and can reach the bees through feeding. Therefore, it is important to analyze the cytotoxicity of this compound in organs involved in the metabolism of food contaminated with insecticide. A major organ for toxicity is the midgut since it is one of the primary organs that comes in contact with the insecticide. Some data show that the epithelium of the bee midgut can be affected by some insecticides that can compromise feeding behaviors (Han et al. 2012).

In bees, the digestive tube is divided into proventriculus, midgut and hindgut (Snodgrass 1956). The midgut is a long, thick cylindrical tube that bends in an arc inside the abdominal cavity and is considered the insect's functional stomach, since most of the digestion and absorption occur in this region (Cruz-Landim 2009).

The midgut is largely composed of two cell types: the main or digestive cells responsible for the synthesis of digestive enzymes and absorption of nutrients and the regenerative cells, which are grouped into nests and replace the main cells when these are removed by use (CruzLandim et al. 1996).
Given the increasing use of insecticides in the Brazilian and world agricultural scenarios, and considering that bees are nontarget insects that can suffer not only with the lethal effects of the use of insecticides but also with the sublethal effects of these compounds, which may affect the physiology, behavior, and longevity of individuals, as well as the health of the whole colony, it is important to analyze specific cellular and protein alterations resulting from exposure to a sublethal concentration. This study thus reinforces the need to analyze the adverse side effects of systemic pesticides on bees through tests that include a broader range of exposure scenarios (Decourtye et al. 2013).

Thus, the objectives of this study were to (1) determine a sublethal concentration based on the value of the mean lethal concentration $\left(\mathrm{LC}_{50}\right)$, (2) analyze the possible ultrastructural alterations in the Kenyon cells of the mushroom bodies in the brains and in the digestive cells in the midguts of these bees after oral exposure to the sublethal concentration, and (3) verify the spatial distribution of specific proteins in the brains of bees exposed to the sublethal concentration of imidacloprid.

\section{Materials and methods}

\section{Biological material}

Honeybees were obtained from queenright colonies of Africanized A. mellifera at the experimental apiary of the Institute of Biosciences of Rio Claro, Department of Biology, University of São Paulo State (UNESP), Rio Claro, SP, Brazil. Colony health conditions were verified based on the guidelines for xenobiotics assessments on bees (OECD 1998).

Five hundred newly emerged honeybees were marked on the thorax with nontoxic ink and returned to the colony for later capture at the age of 21 days. To assure that foragers bees were captured, only marked bees bringing pollen were captured in the entrance of the colony. In this way, we used forager bees with 21 days.

The individuals were kept in $250 \mathrm{~mL}$ cages (volume; twenty bees were placed per cage, such that each treatment contained sixty bees from three colonies), fed in groups through microtubes $(1.5 \mathrm{~mL})$ punched in extremities, and kept in a chamber of biochemical oxygen demand (BOD) at $32 \pm 2{ }^{\circ} \mathrm{C}$, relative humidity of $60 \pm 10 \%$ and in constant darkness. The diet used was composed of $50 \%$ (w/v) aqueous sugar solution. Assays were carried out at the UNESP -Center for the Study of Social Insects (CEIS); all replicates were caught on the same day, and the bees were randomly assigned to the treatments. 


\section{Acute toxicity test}

The procedures for determining the orally administered sublethal concentration were based on the protocol of the OECD-Organization for Economic Cooperation and Development (1998). Each group (control group and group exposed to the different concentrations of imidacloprid) consisted of three replicates, each of them with twenty bees from one colony, for a total of sixty specimens per group.

The control group received a diet composed of an aqueous solution of $50 \%$ sucrose. The insecticide imidacloprid (Imidacloprid Pestanal from Sigma-Aldrich, Brazil) was diluted in acetone (15\%) and water, and later, successive dilutions were performed in order to achieve the following concentrations in the syrup offered to the bees: $0.25,0.5,1$, $2,4,8,16,32$ and $64 \mathrm{ng}$ a.i./uL (ppm) syrup.

All results in this paper refer to nominal concentrations only. Each experimental group received only the respective type of diet during the experiment. The mortality of the individuals was recorded $24 \mathrm{~h}$ after the beginning of food supply and was subjected to Probit analysis software BioStat (version 6.0) (Analystsoft) using the Finney method (log-normal distribution).

\section{Sublethal effects of imidacloprid at the cellular level}

The sublethal concentration of imidacloprid to be added to the diet of the group exposed to the insecticide was based on the acute toxicity test (determination of $\mathrm{LC}_{50}$ ). The acetonic solution (15\%) of imidacloprid was added to this food such that it had a final concentration 100 times lower than the $\mathrm{LC}_{50}\left(\mathrm{LC}_{50 / 100}\right): 0.014651 \mathrm{ng}$ imidacloprid/ $\mu \mathrm{L}$ diet. The acetone concentration in the working solution was $0.00021 \%$. The control group received a diet composed of an aqueous solution of $50 \%$ sucrose. Each of the two experimental groups received only their respective type of diet during the experiment with daily filling of the feeders.

Each group (control and exposed to the sublethal concentration) consisted of three replicates, each of which had twenty bees from each colony (three colonies were used), for a total of sixty specimens per treatment. To analyze the cytotoxic effects of the insecticide using transmission electron microscopy, three individuals were used, with each one being obtained from a different colony (three colonies) to ensure genetic differences among individuals. For each individual, three grids containing four sections were analyzed. This sample number was adopted for ultrastructural analysis and was part of the standard procedure adopted in the laboratory of electron microscopy of UNESP, Rio Claro.

The collection of specimens for studies of ultrastructural alterations in the midgut and brain was based on the exposure period of the bees to imidacloprid on the first, fourth and 8th days after the beginning of food supply such that the immediate and long-term effects of imidacloprid could be investigated.

For MALDI-imaging analysis, the bees were collected 1 day after the beginning of the exposure to determine whether a short exposure can alter the distribution of specific proteins in the brain.

\section{Transmission electronic microscopy}

Honeybees were collected on the first, fourth and 8th days after the beginning of the bioassay. Six samples were taken per treatment/time. Brains and midguts of exposed and control bees were dissected in buffer solution containing 20 $\mathrm{mM} \mathrm{Na} 2 \mathrm{HPO}_{4} / \mathrm{KH}_{2} \mathrm{PO}_{4}$, pH $7.4+130 \mathrm{mM}$ of $\mathrm{NaCl}(\bmod -$ ified from Dade 2009) and fixed in modified Karnovsky (4\% paraformaldehyde, $2.5 \%$ glutaraldehyde in $0.1 \mathrm{M}$ sodium cacodylate buffer, $\mathrm{pH} 7.2$ ) for $2 \mathrm{~h}$ at $4{ }^{\circ} \mathrm{C}$. Once fixed, the organs were washed in the same buffer, post-fixed in $1 \%$ osmium tetroxide in the same buffer for $2 \mathrm{~h}$ at room temperature and washed in the buffer a second time. The post-fixed organs were contrasted in $2 \%$ uranyl acetate in $10 \%$ acetone for $2 \mathrm{~h}$ and then dehydrated in a standard acetone series. The material was embedded in Epon-Araldite resin. Ultrathin sections cut on a Porter Blum ultramicrotome MT2 were stained with lead citrate for $15 \mathrm{~min}$ and examined under the transmission electron microscope (JEOL-JEM1011).

\section{Chemical imaging technique (MALDI-Imaging)}

The bees that were exposed to a sublethal concentration of imidacloprid and the bees of the control group were collected 1 day after the beginning of the experiments and frozen at $-80^{\circ} \mathrm{C}$. The brains of the bees were dissected and sectioned into $12-\mu \mathrm{m}$-thick slices using a cryostat at $-20^{\circ} \mathrm{C}$ (LEICA CM1850). Such slices were carried through the sagittal plane of the head of each worker bee in the region of the major axis of the cephalic capsule.

Subsequent $5 \mu \mathrm{m}$ histological sections were analyzed immediately by histological staining with hematoxylin and eosin (H\&E) and by MALDI-MSI (MALDI-Mass Spectrometry Imaging), enabling the generation of a contour map of the brain of that individual for each cut analyzed such that the spatial distribution of studied proteins could be represented. Several slices were submitted to coloration with H\&E for localization of brain structures. This step is necessary to match the location of the proteins to the structures present in the brains of the bee.

The slices analyzed by MALDI-MSI were previously washed successively with $70 \%(\mathrm{v} / \mathrm{v})$ and $90 \%$ ethanol for 1 min in each solution to eliminate salts and lipids present in the samples. Subsequently, the histological sections were 
subjected to desiccation for $30 \mathrm{~min}$ under ambient temperature in a vacuum-sealed desiccator containing silica gel as desiccant.

The digital images of the tissue sections were captured by a microscope (Olympus BX51TF) connected to a camera (Olympus U-LH100HG). The histological sections stained with $\mathrm{H} \& \mathrm{E}$ were used in the construction of the contour map used for MALDI-MSI data interpretation.

In the analyses of the triptych digests, trypsin autodeposition was done using a CHIP-1000 chemical printer (Shimadzu). The printer was programmed to generate a micro-arrangement of approximately 500 points/analysis, where all points of the matrix solution were spaced $200 \mu \mathrm{m}$ apart from center to center (lateral resolution), totaling 36 points $/ \mathrm{mm}^{2}$ of histological section.

Initially, each spot received $20 \mathrm{~nL}$ of a solution containing $20 \mathrm{mg} / \mathrm{mL}$ of trypsin in $20 \mathrm{mM}$ of $\mathrm{NH}_{4} \mathrm{HCO}_{3}$ buffer (pH 8.0) and incubated for $2 \mathrm{~h}$ at $37^{\circ} \mathrm{C}$. The section was later incubated for $2 \mathrm{~h}$ in a humid atmosphere at $37^{\circ} \mathrm{C}$. Next, a solution containing $10 \mathrm{mg} / \mathrm{mL}$ of cinnamic acid (CHCA) in acetonitrile solution 50\% (v/v) containing trifluoroacetic acid (TFA), $1 \%(\mathrm{v} / \mathrm{v})$ was used as a matrix for analysis of the triptych digests, being applied $500 \mathrm{pL}$ ( 5 drops of $100 \mathrm{pL}$ ) of matrix/point solution. After the application of the matrix, the histological sections were submitted to the process of desiccation for $10 \mathrm{~min}$ at room temperature. Planar coordinates $(x$ and $y$ ) created by the ChIP-1000 were saved and exported to the mass spectrometer.

The MALDI-MS spectra were obtained in the positive reflectron mode by a MALDI ToF-ToF (AXIMA Performance, Shimadzu) instrument equipped with an N2 laser SmartBeam, controlled by the Launchpad algorithm v2.8 (Shimadzu). ACTH peptides (fragment 18-39) and Angiotensin II were used for the calibration of the instrument. Spectra of MALDI-MS were acquired in the range of 700 to $4000 \mathrm{~m} / \mathrm{z}$ with a total of 250 laser shots/sample preparation point, fired only in the coordinates set ( $x$ and $y$ ) mentioned above. Approximately 125,000 laser shots per analyzed sample were carried out, creating a mass spectrum for each laser shot (generating a total of 125,000 spectra/sample). MS/MS spectra were obtained in the positive mode with the "reflectron" device activated, with the CDL system adjusted to $200^{\circ} \mathrm{C}$, and the pressure of the ToF region adjusted to $1.5 \times 10^{-4} \mathrm{~Pa}$, ion accumulation time at $50 \mathrm{~ms}$ and the collision gas level at $30 \%$. Under these conditions, a mass error of $3.00 \mathrm{ppm}$ and a resolution of 10,000 FWHM were obtained.

\section{Protein identification}

The protein identification was accomplished by analyzing MS/MS spectra through the bioinformatics tool Mascot v2.3 using a protein bank restricted to the genus Apis (NCBI). The research parameters used were (i) the absence of protein molecular weight restrictions; (ii) cleavage triptych loss adjusted to 01 ; (iii) fixed changes in oxidation: methionine; and (iv) variable changes: carbamidomethylation. The tolerance errors used in the search were from $0.5 \mathrm{Da}$ for MS and 0.3 for MS/MS.

\section{Spectral imaging data processing}

Through the use of the Launchpad v2.8 algorithm (Shimadzu) the raw data (.raw) were converted to the format. $\boldsymbol{m} \boldsymbol{z} \boldsymbol{X M L}$. The images were rebuilt in MSiReader $\mathrm{v} 0.05$ algorithm from the data in the format.mzXML using a mass tolerance of $\pm 0.3 \mathrm{DA}$ and spacing of $200 \mu \mathrm{m}$. In this algorithm, the following parameters were configured: the method used to calculate the intensity displayed in molecular images was the Max of Window (Max); subtraction of noise and background; baseline correction; standardization of data based on the intensity of the internal standard 2Phenylethylamine, $m / z, 122.18$ in the form $[\mathrm{M}+\mathrm{H}]+$; and cubic interpolation of order 5 of the images' pixels.

\section{Analysis of the images-creation of contour maps}

After the acquisition of data, the molecular images of the identified proteins were rebuilt from the values of the $\mathrm{m} / \mathrm{z}$ of molecular ions in the monoprotonated form $([\mathrm{M}+\mathrm{H}]+)$ of the triptych peptides using the MSiReader v0.05 algorithms, a free open source platform built on the platform of the Matlab (Mathworks, Natick, MA, USA).

To correlate the special distribution of proteins with their locations in the brains of bees, we created a contour map based on the 3D Digital Atlas of the Honeybee Brain A. mellifera, developed by Rybak et al. (2010) in which the limits of each nerve center were set to assist with the interpretation of data from MSI. The standard atlas of the bee's brain (Honeybee Brain Standard Atlas-HSB atlas, http://www.neurobiologie.fu-berlin.de/beebrain/) was calculated from 20 individual brains, stained using immunohistochemistry techniques; the images were generated using confocal microscopy and threaded along the borders of 22 nerve centers. Finally, a three-dimensional surface model was reconstructed from the data obtained (Rybak et al. 2010).

Subsequently, the contour map was plotted on the image obtained for each section as described above for the H\&E staining, enabling the anatomical visualization of the brain in the sagittal section and facilitating the alignment of the molecular images obtained by mass spectrometry with the histochemical images. In this way, a mask containing the anatomical limits of each nerve structure was created, enabling the analysis of the images generated by MALDI- 
MSI. After the development of the contour map, the structures were named according to the HSB atlas.

\section{Results}

\section{Acute toxicity}

Based on toxicity tests, the oral $\mathrm{LC}_{50}$ value for imidacloprid in Africanized honey bees was determined as $1.465 \mathrm{ng} / \mu \mathrm{L}$ in syrup (ppm) (Table 1). From this value, the sublethal concentration corresponding to $\mathrm{LC}_{50 / 100}$ was calculated as $0.014651 \mathrm{ng}$ imidacloprid $/ \mu \mathrm{L}$ diet, which was used in the sublethal experiments.

\section{Transmission electron microscopy}

\section{Midgut}

The midgut analysis revealed that the digestive cells of untreated bees showed typical ultrastructural characteristics (Fig. 1a, d and g). Nuclei with spherical shape and without expansion in the perinuclear region were observed (Fig. 1b, e and $h$ ), as were organelles with no alterations, especially mitochondria with double membrane and evident cristae (Fig. 1c, f and i).

Ultrastructural analysis of the group exposed to the sublethal concentration of imidacloprid on the 1st day showed no ultrastructural alterations in digestive cells (Fig. 2a, b, and c). However, after 4 days of exposure, the alterations resulting from the action of the insecticide were quite evident in the nucleus. Most of the nuclei analyzed presented electron-lucid regions in the nuclear matrix (Fig. 2d). In addition, it was possible to observe some nuclei in advanced stages of degeneration, with reduced sizes and very condensed chromatin (Fig. 2e). Mitochondria did not show evident signs of degeneration (Fig. 2f).

On the 8th day of analysis, the presence of large secretory vacuoles in the cytoplasm of the cells (Fig. 2h), digestive vacuoles (Fig. 2g) and dilated mitochondria with losses of matrix, double membrane and mitochondrial cristae were observed (Fig. 2i).

Table 1 Median lethal concentration $\left(\mathrm{LC}_{50}, \mathrm{ng} / \mu \mathrm{l}\right)$ of imidacloprid to Apis mellifera after $24 \mathrm{~h}$ exposure to contaminated syrup

\begin{tabular}{llllll}
\hline Exposure mode & Time (h) & LC $_{50}{ }^{\mathrm{a}}$ & C.I. $^{95 \% \mathrm{~b}}$ & $\chi^{2 \mathrm{c}}$ & D.F. $^{\mathrm{d}}$ \\
\hline Ingestion & 24 & 14,651 & $10,203-20,073$ & 37,848 & 7 \\
\hline
\end{tabular}

$h=$ hours, $\mathrm{a}=$ Median Lethal Concentration, $\mathrm{b}=95 \%$ confidence interval, $\mathrm{c}=$ chi-square, $\mathrm{d}=$ freedom degree

\section{Brain}

In the control group from the first, fourth and 8th days, the Kenyon cells presented typical ultrastructural characteristics: nuclei with regular shape and uniform perinuclear space (Fig. 3b, e, and h), cytoplasm with organelles without alterations (Fig. 3a, d and g), mitochondria with a double membrane, preserved mitochondrial cristae and homogeneous matrix (Fig. 3c, f, and i).

However, several alterations were observed in these cells in the presence of the insecticide. On the 1st day of exposure to the sublethal concentration, it was possible to notice altered mitochondria, which were visibly dilated with a loss of electron density and cristae (Fig. 4c). In addition, phagosomes were found in the cytoplasm (Fig. 4c), indicating degradation and digestion of cellular debris. The nuclei of the cells did not exhibit alterations (Fig. 4a and b).

On the 4th day of exposure to imidacloprid, cellular alterations were more evident. In addition to the chromatin condensation and marginalization, several nuclei were more irregular (Fig. 4e). The insecticide also caused dilatation of perinuclear space (Fig. 4e) and alterations in mitochondria (Fig. 4f). A characteristic observed exclusively in this group was the presence of some electron lucid regions among the Kenyon cells in the brain (Fig. 4d).

The ultrastructural analysis of the brains of bees exposed to insecticide for 8 days again showed mitochondrial alterations and the presence of cytoplasmic vacuoles (Fig. 4i).

\section{MALDI-imaging}

Based on the analysis of protein distribution through chemical imaging, it was possible to observe an increase in the relative expression of the proteins: vascular endothelial growth factor receptor (Fig. 5a), amyloid protein precursor (Fig. 5b) and protein kinase C (Fig. 5d), in individuals exposed to imidacloprid on the 1st day. There was a decrease in the relative expression of nicotinic acetylcholine receptor alpha 1 (Fig. 5c) in the brain caused by the $\mathrm{LC}_{50 /}$ 100 of the insecticide.

\section{Discussion}

This study aimed to measure the lethal exposure levels (represented by $\mathrm{LC}_{50}$ ) in order to determine a sublethal concentration for the other experiments. The $\mathrm{LC}_{50}$ value is a measure of environmental exposure, useful for spray exposures, as well as contaminated food, but since it is the actual ingested dose that kills the bees, the $\mathrm{LC}_{50}$ can vary considerably, depending on the feeding amounts by the 

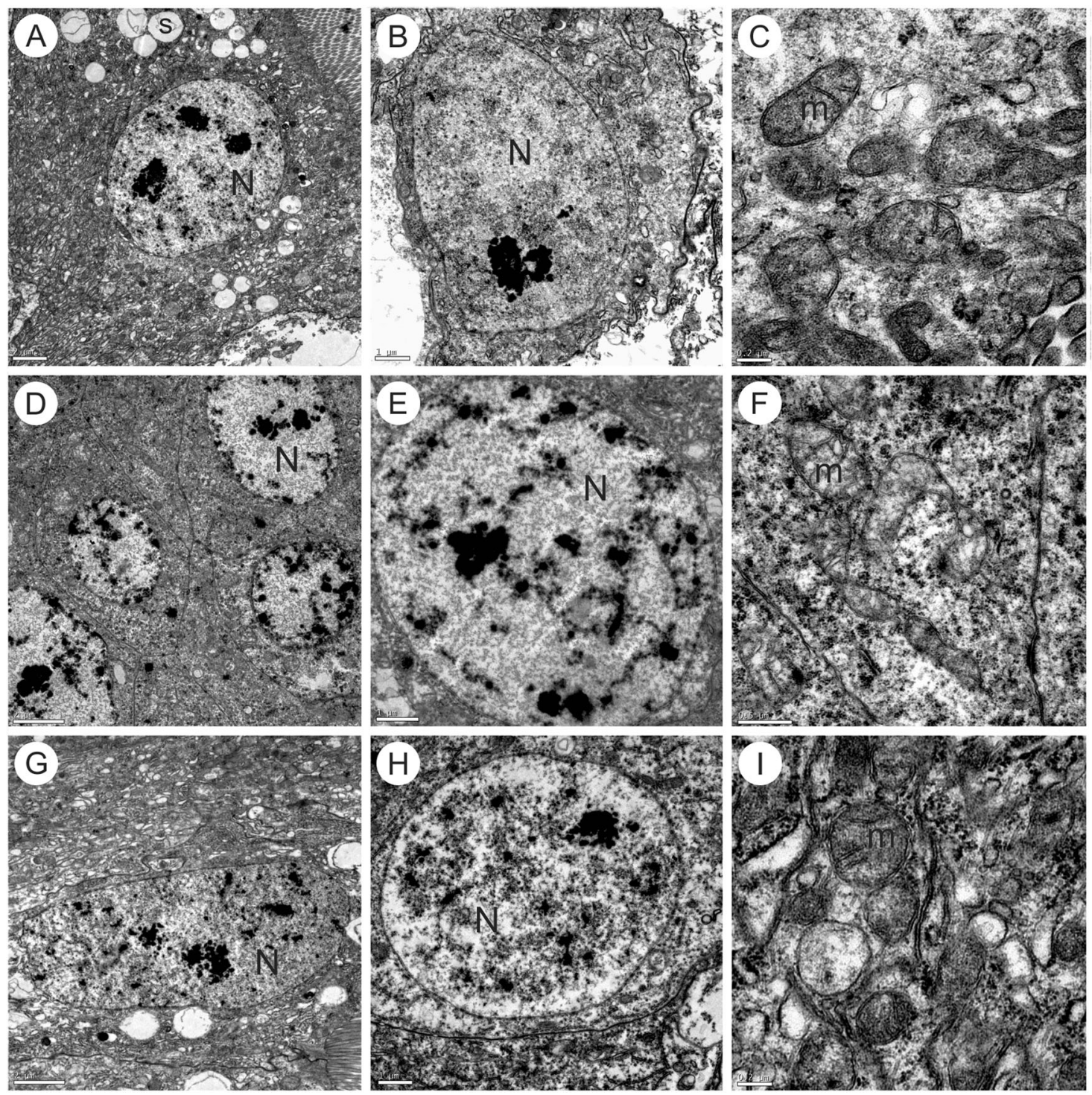

Fig. 1 Transmission electron micrographs of digestive cells from the midgut of A. mellifera not exposed to a sublethal concentration of imidacloprid. a, b and $\mathbf{c}$ Control group -1 day; $\mathbf{d}$, e and $\mathbf{f}$ Control

particular bees being tested, the subspecies chosen (Laurino et al. 2013) and other conditions.

The sublethal concentration used, $0.014651 \mathrm{ng}$ imidacloprid/ $\mu \mathrm{L}$ diet (14.6 ppb), is relevant since residues of this insecticide in pollen and nectar in the field are in the range of 1 to $20 \mathrm{ppb}$ (Blacquiere et al. 2012; Sanchez-Bayo and Goka 2014).

The $\mathrm{LC}_{50}$ of imidacloprid was established as $2.01 \mathrm{ng}$ a.i./ $\mu \mathrm{L}$ diet for $24 \mathrm{~h}$ and $0.81 \mathrm{ng}$ a.i. $/ \mu \mathrm{L}$ diet for $48 \mathrm{~h}$ in Melipona scutellaris bees (Costa et al. 2015). Based on these values, this insecticide shows a similar toxicity for both the Africanized and the native bees. Conversely, the value found in this work as the oral $\mathrm{LC}_{50}$ of imidacloprid (1.46 $\mathrm{ppm}$ ) was quite different from the $\mathrm{LC}_{50}$ value for commercial solution sprays (e.g., topical exposure) (Bailey et al. group-4 days; $\mathbf{g}, \mathbf{h}$ and $\mathbf{i}$ Control group -8 days. $\mathrm{N}$ nuclei, $\mathrm{m}$ mitochondria, s spherocrystal. Obs preserved cells without compromising nucleus and organelles

2005). This difference is primarily observed because oral exposure to systemic insecticides results in higher toxicity than topical exposure to spray droplets; these compounds are water soluble and are not taken up easily through the insect's cuticle.

The toxicity of thiamethoxam was evaluated for $A$. mellifera, and the $\mathrm{LC}_{50}$ was $4.28 \mathrm{ng}$ a.i./ $\mu \mathrm{L}$ diet (Oliveira et al. 2014). This insecticide also belongs to the class of neonicotinoid and neurotoxic insecticides, the action of which is similar to that of imidacloprid. Imidacloprid, which a lower $\mathrm{LC}_{50}$ value, seems to be more toxic to these bees than thiamethoxam, indicating that lower doses can alter the survival of individuals.

In addition to determining the lethal oral exposure to imidacloprid for A. mellifera forager bees, the present work 

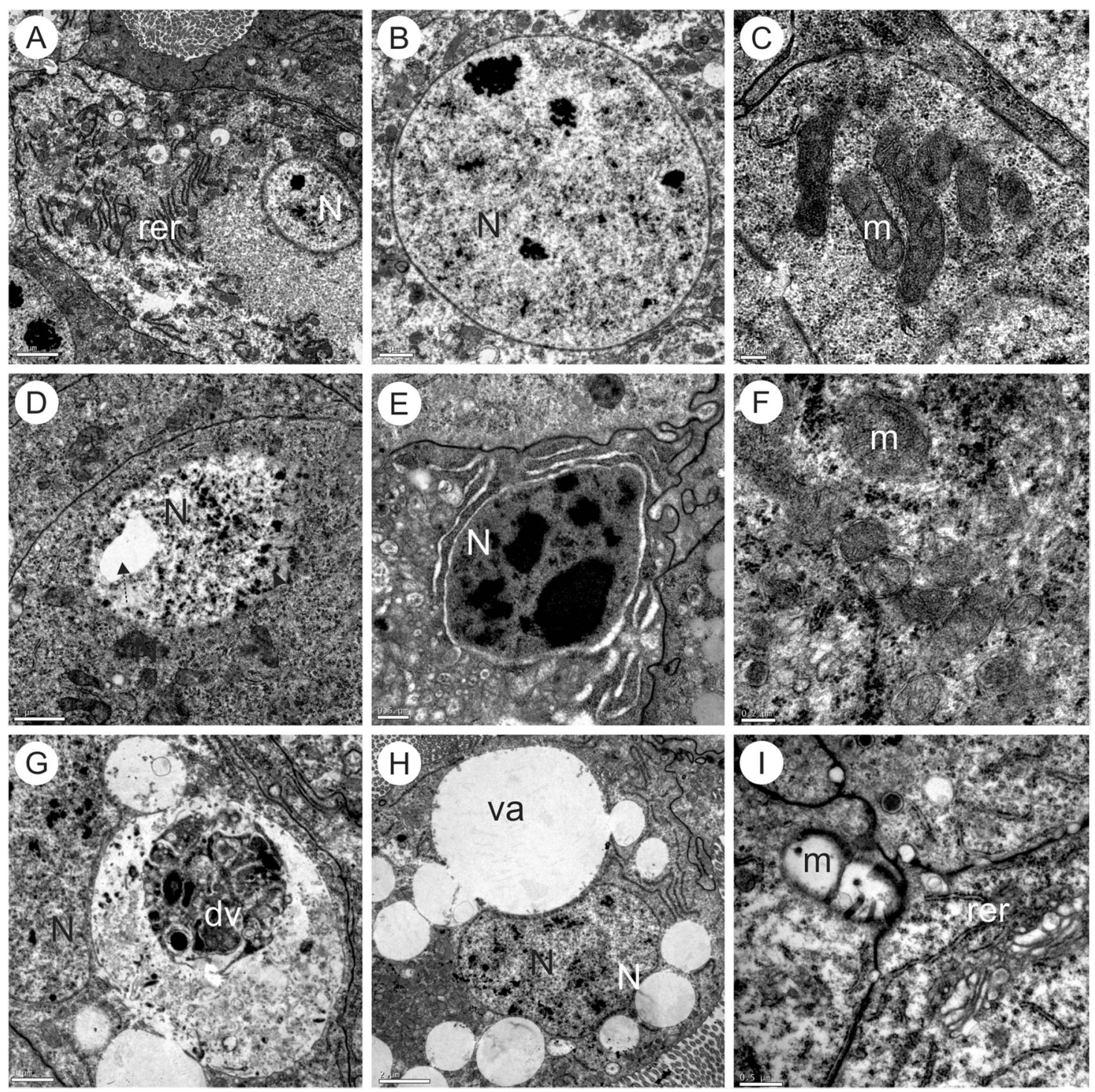

Fig. 2 Transmission electron micrographs of digestive cells from the midgut of A. mellifera exposed to a sublethal concentration of imidacloprid. a, $\mathbf{b}$ and $\mathbf{c}$ Group exposed to imidacloprid for 1 day; $\mathbf{d}, \mathbf{e}$ and f Group exposed to imidacloprid for 4 days; $\mathbf{g}, \mathbf{h}$ and $\mathbf{i}$ Group exposed

to imidacloprid for 8 days. $\mathrm{N}$ nuclei, $\mathrm{m}$ mitochondria, rer rough endoplasmic reticulum, va secretion vacuole, dv digestive vacuole. Observe the electron lucid regions in the nucleus indicated by the dashed arrow

has also aimed to study the possible effects of this insecticide in the bee midgut and brain by transmission electron microscopy. The ultrastructural alterations in the cells of these two organs were also evaluated in the work of Oliveira et al. (2014), due to the exposure to the insecticide thiamethoxam. The comparison of the results obtained for these two insecticides thus becomes quite interesting.

In relation to the midgut of bees, the organ that first comes in contact with the insecticide, the results showed that a 1-day exposure to the insecticide does not alter the ultrastructure of the digestive cells. In the digestive cells, it is possible to observe three distinct zones: the basal zone, with many invaginations of the plasmatic membrane; the median, with the nucleus, rough endoplasmic reticulum and
Golgi; and the apical, with secretion granules beside mitochondria and microvilli (Cruz-Landim 2009).

However, the alterations observed in the digestive cells of bees exposed to the same levels of insecticide for a longer period show that imidacloprid is cytotoxic. Thereby, individuals exposed for 4 days to the sublethal concentration of imidacloprid presented cell nuclei with chromatin condensation and evident disorganization of the nuclear envelope. Chromatin condensation is a typical feature of apoptosis and is related to decreased activity of the cells that will suffer degeneration (Kerr et al. 1972; Cruz-Landim and Cavalcante 2003; Silva-Zacarin et al. 2007).

It is known that digestive cells have a limited lifetime, decreasing further in pathological and/or toxicological 

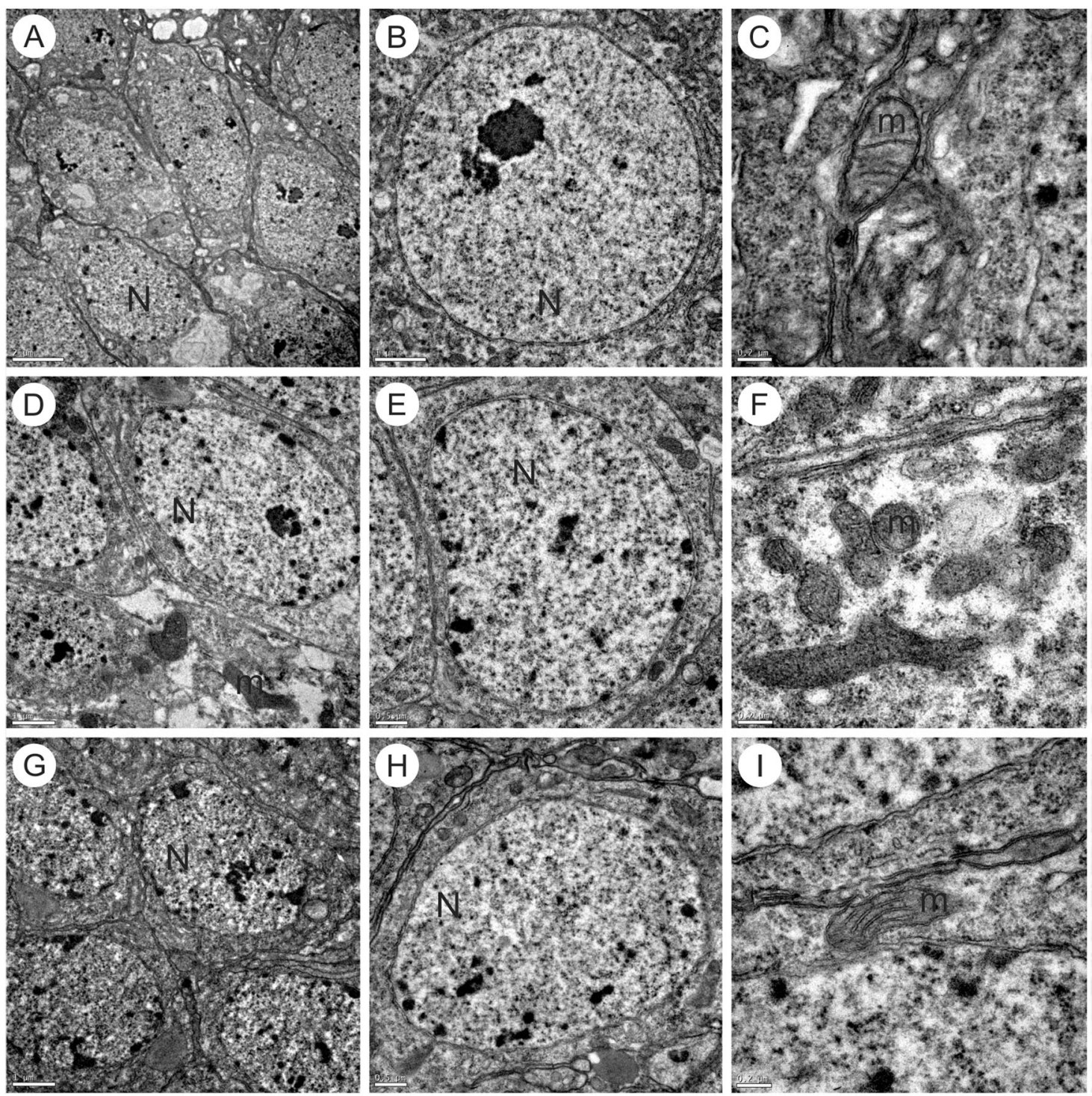

Fig. 3 Transmission electron micrographs of Kenyon cells of the brain of A. mellifera not exposed to a sublethal concentration of imidacloprid. a, b and c Control group-1 day; d, e and f Control group-4 days;

situations with an increased amount of degenerating cells (Bowen et al. 1998). This phenomenon was also observed in the present study, in which the bees exposed for 8 days to imidacloprid presented digestive cells with ultrastructural features that indicated cellular death. On the 8th day, the presence of digestive vacuoles in the cytoplasm was observed and mitochondria, which until then had not been damaged, began to show important signs of degradation, such as swelling and losses of matrix, double membrane and mitochondrial cristae.

According to Häcker (2000), mitochondria may remain physically intact in the early stages of cell death. However, the loss of mitochondrial matrix content can also be observed in cells that undergo this process. Mitochondrial g, h and i Control group-8 days. $\mathrm{N}$ nuclei, $\mathrm{m}$ mitochondria. Obs preserved cells without compromising nuclei and organelles

damage causes alterations in the permeability of the membranes, the release of death-activating proteins and interruption of ATP synthesis (Loeffler and Kroemer 2000; Grivicich et al. 2007). Gregorc and Ellis (2011), using the TUNEL technique, observed that larvae that had a diet contaminated with imidacloprid presented a $61 \%$ higher incidence of death in midgut cells.

Other authors have examined the effects of thiamethoxam, another neurotoxic insecticide, on forager honeybees using morphological and histochemical techniques. This compound caused cytoplasmic vacuolation, an increase of apocrine secretion and reduction in the number of regenerative epithelium cells (Oliveira et al. 2014). Thiamethoxam also caused disorganization in the smooth 

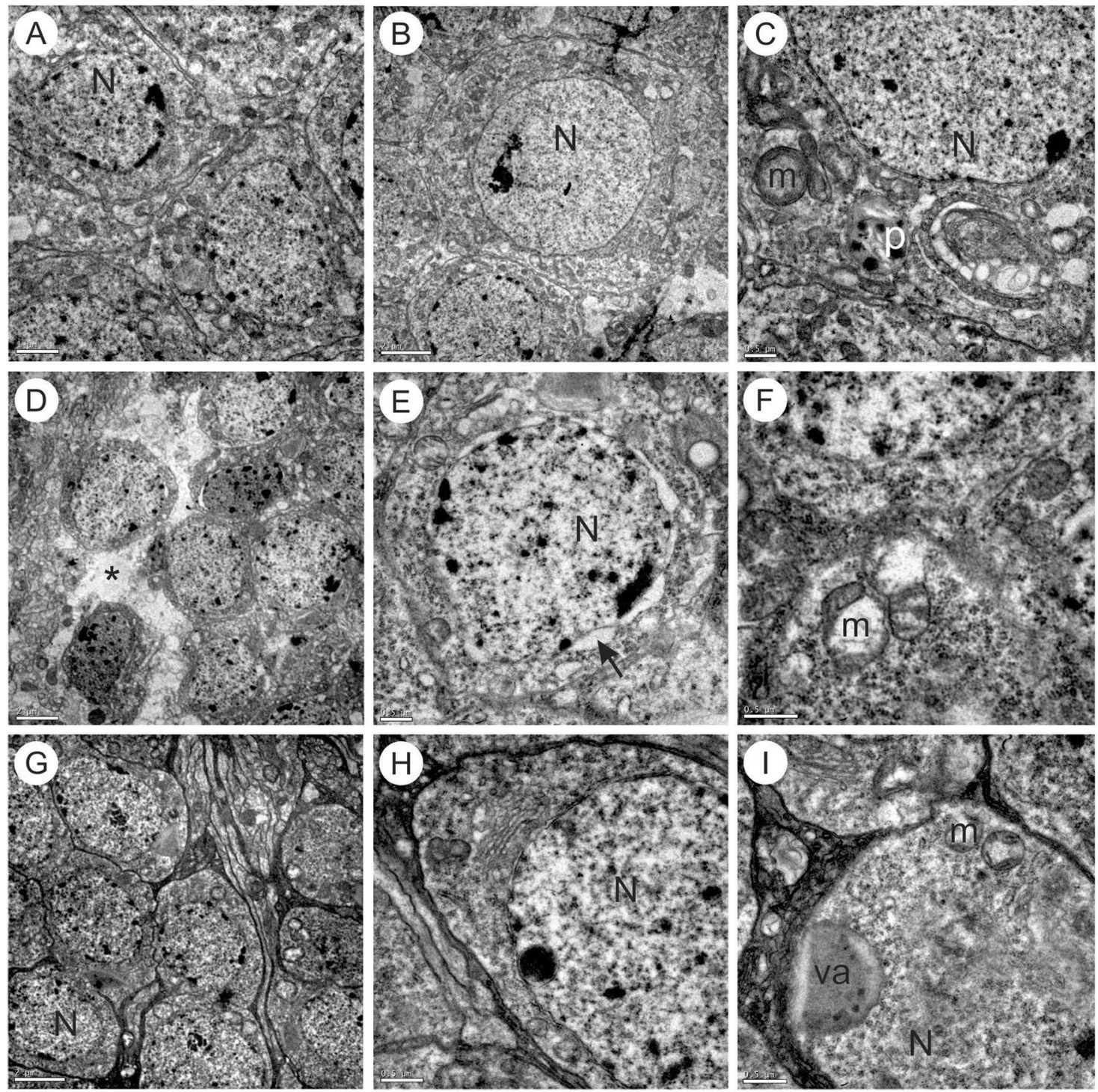

Fig. 4 Transmission electron micrographs of Kenyon cells of the brain of A. mellifera exposed to a sublethal concentration of imidacloprid. a, $\mathbf{b}$ and $\mathbf{c}$ Group exposed to imidacloprid for 1 day; $\mathbf{d}$, e and $\mathbf{f}$ Group exposed to imidacloprid for 4 days; $\mathbf{g}, \mathbf{h}$ and $\mathbf{i}$ Group exposed to

reticulum, nuclear and mitochondrial alterations, and the presence of cytoplasmic vacuoles in the midgut of newly emerged A. mellifera bees; however, on the 8th day of exposure, there was an observed organ recovery, possibly by the action of the Malpighian tubules and detoxification proteins (Catae et al. 2014). This recovery in the cells of the midgut was not observed in our results on day 8 .

All of the alterations observed show the high cytotoxicity of imidacloprid to the digestive cells of the midgut, highlighting that a field realistic concentration (14.6 ppb), such as that evaluated in this work, was able to compromise the cells and can also affect the functions performed by that organ. imidacloprid for 8 days. $\mathrm{N}$ nuclei, $\mathrm{m}$ mitochondria, va vacuole, $\mathrm{p}$ phagosome. Observe the spaces between the membranes of the nuclear envelope (arrow) and the spaces between the Kenyon cells (asterisk)

While the midgut presents proteins such as glutathione $\mathrm{S}$ transferase, cytochrome P450, and carboxylesterase, which are involved in detoxification processes (Claudianos et al. 2006), the results obtained in this work suggest that these proteins were unable to avoid damage caused by imidacloprid, as these were more significant over the days of exposure. While it appears that detoxification through the digestive cells did not occur, imidacloprid reached the target organ, the neurons, as evidenced by the ultrastructural alterations observed in the brain in the present study.

Mitochondria showed ultrastructural alterations since the beginning of the analyses, after exposure to the insecticide. This organelle is extremely important for the performance 
Fig. 5 Relative expression of proteins involved with oxygen supply, neuronal degeneration, synapses and memory/learning in the brain of $A$. mellifera exposed or not exposed to a sublethal concentration of imidacloprid for 1 day. The scale of colors represented in the right side of the images represents the relative concentrations of the proteins. The peak of highest intensity was taken as $100 \%$ (represented in red) and the blue color indicates lower relative concentration of this protein. a Vascular endothelial growth factor receptor. b Amyloid protein precursor. c: nicotinic acetylcholine receptor alpha 1 . d Protein kinase C. The pattern of coloring represents the relative concentration of a protein, ranging from 0 to $100 \%$. High concentrations of proteins are represented through $100 \%$ intensity and feature coloring in red while decreasing intensity gradient colors represent smaller concentrations of protein
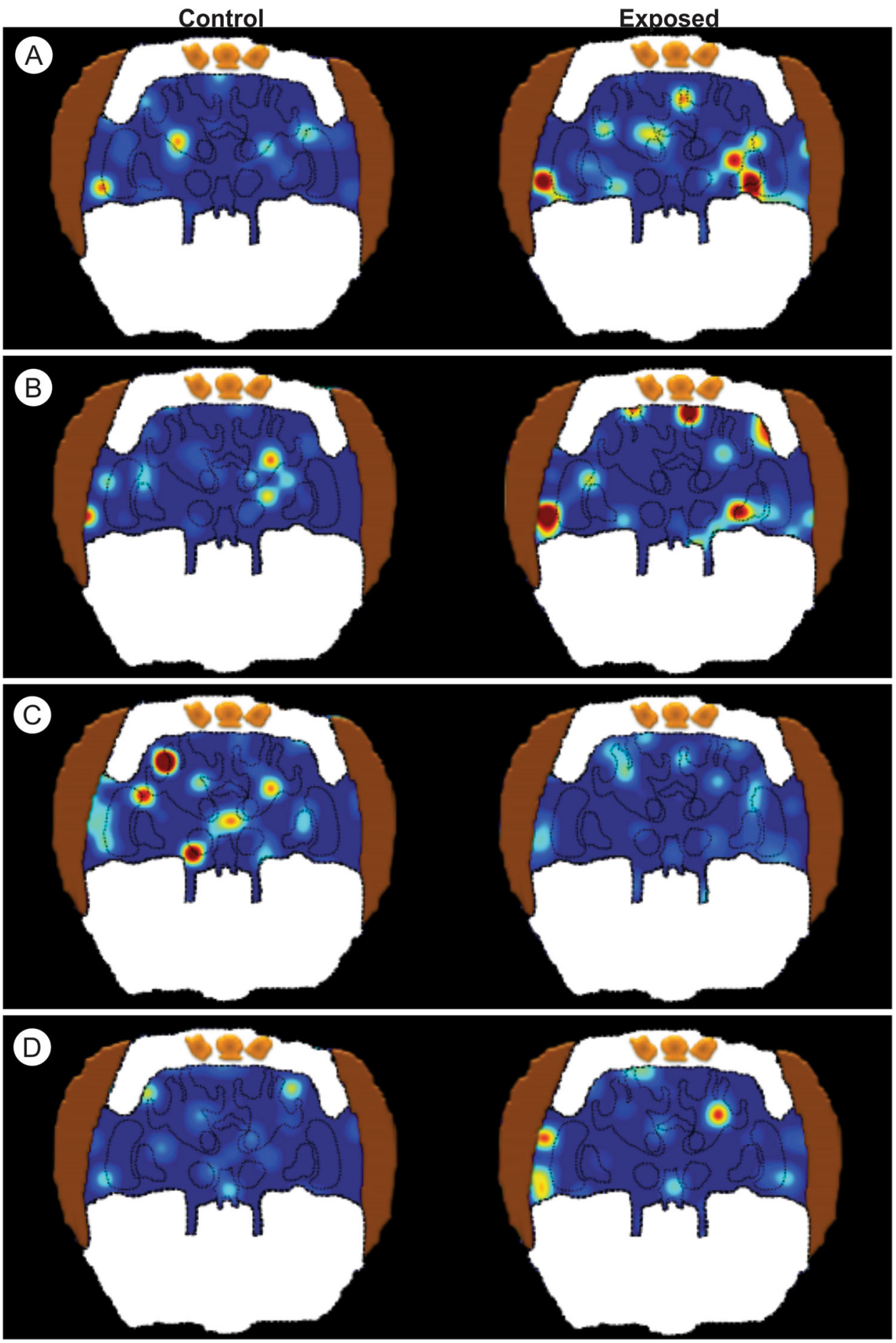

of cellular functions, mainly because it is responsible for the accumulation of energy in the form of ATP. Fipronil and imidacloprid are considered inhibitors of mitochondrial bioenergetics insecticides, resulting in depletion of ATP (Nicodemo et al. 2014). Mitochondrial impairment is closely related to the oxygen supply damage, also evidenced by alterations in the expression of VEGF, a protein which has increased expression in hypoxic conditions (Risau 1997).

Neurons are very dependent on normal mitochondrial function since the release of neurotransmitters from synapses requires large amounts of energy (Chen and Chan 2006). Alterations in the expression and distribution of the nicotinic acetylcholine receptor strengthen the damage in 
the transmission of nerve impulses, the target of the imidacloprid process, which acts as an acetylcholine agonist (Buckingham et al. 1997).

As mitochondria were altered in all stages studied, ATP production was not reestablished, and other cell structures were also altered, such as the nucleus. The nuclear alterations were more prominent on the 4th day of exposure to imidacloprid, the period during which many nuclei presented irregular shape and dilated perinuclear spaces.

The intercellular spaces, larger in the presence of imidacloprid, indicate damage in cell-cell contact probably due to alterations in the cytoskeleton, the structure responsible for cell adhesion. The loss of cell-cell contact can lead to tissue disruption.

Oliveira et al. (2014) analyzed the effects of sublethal doses of thiamethoxam in the brains of forager Africanized A. mellifera and showed morphological and histochemical alterations in mushroom bodies and optical lobes, such as cytoplasmic and nuclear condensation and vacuolation. Sublethal doses of imidacloprid also caused cytotoxic effects in the brain. Pyknotic nuclei with condensed chromatin and increased protein synthesis in certain cells were noted in individuals exposed to imidacloprid, suggesting cell death (Rossi et al. 2013). These results were also observed in bees Scaptotrigona postica exposed to fipronil insecticide (Jacob et al. 2015).

The evident increase in the expression of a neuronal degeneration indicator protein, the amyloid precursor, evidences this detriment observed in cells by transmission electron microscopy analysis. These proteins assist in the control and inhibition of aggregation of $\beta$-amyloid, a neurotoxic fragment (Wilhelmus et al. 2006a, b).

The mushroom bodies are important structures related to learning and memory (Cruz-Landim 2009). The fact that such structures suffer significant damage by exposure to imidacloprid could result in impairments in the orientation of individuals in the processing of information in the nervous system and in the effectiveness of collecting food during foraging activities (Decourtye et al. 2004; Desneux et al. 2007; Feltham et al. 2014). Thus, the alterations promoted by imidacloprid are related to damage in memory, learning and guidance, which is confirmed by the alteration in the expression of a protein involved in these processesprotein kinase $\mathrm{C}$.

The alterations corresponding to the relative protein expression were generally observed in the regions of the mushroom bodies, the optic lobes, and the antennal lobes. Such structures are related to the processing of information in the nervous system, the capture of visual stimuli, and reception of olfactory stimuli, respectively, indicating that processes can be compromised by the insecticide.

In conclusion, this paper provides the oral $\mathrm{LC}_{50}$ of imidacloprid for Africanized honeybees, and it was observed that imidacloprid, even at a low concentration, as in the case of $\mathrm{LC}_{50 / 100}$, caused very evident damage in the midgut and brain of bees.

The ultrastructural alterations observed show that imidacloprid is cytotoxic for the brain and even for a non-target organ, causing side effects in Kenyon cells and digestive cells. In addition, the sublethal concentration of imidacloprid affected the distribution of specific proteins in the brain of bees, indicating alterations in oxygen supply, synapses, neuronal degeneration, and could thus explain the deficiencies in learning and memory processes that can compromise the behavior of individuals and the health of the colony. Ethis statement lacking.

\section{Compliance with ethical standards}

Conflict of interest The authors declare that they have no competing interests.

\section{References}

Amaral E, Alves SB (1979) Insetos úteis. Livroceres, Piracicaba

Blacquiere T, Smagghe G, Van Gestel CA, Mommaerts V (2012) Neonicotinoids in bees: a review on concentrations, side-effects and risk assessment. Ecotoxicology 21:973-992. https://doi.org/ 10.1007/s10646-012-0863-x

Bailey J, Scott-Dupree C, Harris R, Tolman J, Harris B (2005) Contact and oral toxicity to honey bees (Apis mellifera) of agents registered for use for sweet corn insect control in Ontario, Canada. Apidologie 36:623-633. https://doi.org/10.1051/apido:2005048

Bonmatin JM, Giorio C, Girolami V, Goulson D, Kreutzweiser DP, Krupke C, Liess M, Long E, Marzaro M, Mitchell EAD, Noome DA (2015) Environmental fate and exposure; neonicotinoids and fipronil. Environ Sci Pollut Res Int 22:35. https://doi.org/10.1007/ s11356-014-3332-7

Bowen ID, Bowen SM, Jones AH (1998) Mitosis and apoptosis: Matters of life and death. Chapman \& Hall, London

Buckingham S, Lapied B, Corronc HL, Sattelle F (1997) Imidacloprid actions on insect neuronal acetylcholine receptors. J Exp Biol 200:2685-2692

Catae AF, Roat TC, Oliveira RA, Nocelli RCF, Malaspina O (2014) Cytotoxic effects of thiamethoxam in the midgut and malpighian tubules of Africanized Apis mellifera (Hymenoptera: Apidae). Microsc Res Tech 77:274-281. https://doi.org/10.1002/jemt. 22339

Chen H, Chan DC (2006) Critical dependence of neurons on mitochondrial dynamics. Curr Opin Cell Biol 18:453-459. https://doi. org/10.1016/j.ceb.2006.06.004

Claudianos C, Ranson H, Johnson RM, Biswas S, Schuler MA, Berenbaum MR, Feyereisen R, Oakeshott JG (2006) A deficit of detoxification enzymes: pesticide sensitivity and environmental response in the honeybee. Insect Mol Biol 15:615-636. https:// doi.org/10.1111/j.1365-2583.2006.00672.x

Costa LM, Grella TC, Barbosa RA, Malaspina O, Nocelli RCF (2015) Determination of acute lethal doses $\left(\mathrm{LD}_{50}\right.$ and $\left.\mathrm{LC}_{50}\right)$ of imidacloprid for the native bee Melipona scutellaris Latreille, 1811 (Hymenoptera: Apidae). Sociobiology 62:578-582. https://doi. org/10.13102/sociobiology.v62i4.792 
Crepet WL (1983) The role of insect pollination in the evolution of the angiosperms. Pollinat Biol 29:50. https://doi.org/10.1016/B9780-12-583980-8.50010-7

Cruz-Landim C (2009) Abelhas: morfologia e função de sistemas. SciELO-Ed, São Paulo

Cruz-Landim C, Cavalcante VM (2003) Ultraestructural and cytochemical aspects of metamorphosis in the midgut of Apis mellifera L. (Hymenoptera: Apidae: Apinae). Can J Res 20:1099-1107. https://doi.org/10.2108/zsj.20.1099

Cruz-Landim C, Silva-de-Moraes RLM, Serrão E (1996) Ultraestrutural aspects of epitelial renewal in the midgut of adult worker bees (Hymenoptera, Apidae). J Comp Biol 1:29-40

Dade HA (2009) Anatomy \& dissection of the honeybee. Cardif: International Bee Research Association, London

Daly HV, Doyen JT, Purcell III AH (1998) Introduction to insect biology and diversity. University Press, Oxford

Decourtye A, Armengaud C, Renou M, Devillers J, Cluzeau S, Gauthier M, Pham-Delègue MH (2004) Imidacloprid impairs memory and brain metabolism in the honeybee (Apis mellifera L.). Pest Biochem Physiol 78:83-92. https://doi.org/10.1016/j.pestbp. 2003.10.001

Decourtye A, Henry M, Desneux N (2013) Environment: overhaul pesticide testing on bees. Nature 497:188-188. https://doi.org/10. $1038 / 497188 \mathrm{a}$

Desneux N, Decourtye A, Delpuech JM (2007) The sublethal effects of pesticides on beneficial arthropods. Annu Rev Entomol 52:81-106. https://doi.org/10.1146/annurev.ento.52.110 405.091440

Elbert A, Haas M, Springer B, Thielert W, Nauen R (2008) Applied aspects of neonicotinoid uses in crop protection. Pest Manag Sci 64:1099-1105. https://doi.org/10.1002/ps.1616

Fahrbach S (2006) Structure of the mushroom bodies of the insect brain. Annu Rev Entomol 51:209-232. https://doi.org/10.1146/a nnurev.ento.51.110104.150954

FAO (2004) Conservation and management of pollinators for sustainable agriculture - the international response. In: Freitas BM, Pereira JOP (eds) Solitary bees: conservation, rearing and management for pollination. Imprensa Universitária, Fortaleza, p 2-19

Farris SM, Sinakevitch I (2003) Development and evolution of the insect mushroom bodies: towards the understanding of conserved developmental mechanisms in a higher brain center. Arthropod Struct Dev 32:79-101. https://doi.org/10.1016/S1467-8039(03) 00009-4

Feltham H, Park K, Goulson D (2014) Field realistic doses of pesticide imidacloprid reduce bumblebee pollen foraging efficiency. Ecotoxicology 23:317-323. https://doi.org/10.1007/s10646-0141189-7

Freitas BM, Pinheiro JN (2010) Efeitos sub-letais dos pesticidas agrícolas e seus impactos no manejo de polinizadores dos agroecossistemas brasileiros. Oecologia Australis 14:282-298. https://doi.org/10.4257/oeco.2010.1401.17

Friedman JW, Shmida A (1995) Pollination, gathering nectar and the distribution of flower species. J Theor Biol 175:127-138. https:// doi.org/10.1006/jtbi.1995.0125

Gallo DN, Neto OS, Carvalho S, Baptista RPL (2002) Entomologia agrícola. Fundação de Estudos Agrários Luiz de Queiroz, Piracicaba

Gregorc A, Ellis JD (2011) Cell death localization in situ in laboratory reared honey bee (Apis mellifera L.) larvae treated with pesticides. Pest Biochem Physiol 99:200-207. https://doi.org/10.1016/ j.pestbp. 2010.12 .005

Griswold T, Parker FD, Hanson PE (1995) The bees (Apidae). In: Hanson PE, Gauld ID (eds) The Hymenoptera of Costa Rica. Oxford University Press, Oxford, p 650-691
Grivicich I, Regner A, Rocha AB (2007) Morte celular por apoptose. Rev Bras Cancerol 53:335-343

Häcker G (2000) The morphology of apoptosis. Cell Tissue Res 301:5-17

Han P, Niu CY, Biondi A, Desneux N (2012) Does transgenic Cry1Ac + CpTI cotton pollen affect hypopharyngeal gland development and midgut proteolytic enzyme activity in the honey bee Apis mellifera L.(Hymenoptera, Apidae)? Ecotoxicology 1-8. https:// doi.org/10.1007/s10646-012-0976-2

Jacob CR, Soares HM, Nocelli RC, Malaspina O (2015) Impact of fipronil on the mushroom bodies of the stingless bee Scaptotrigona postica. Pest Manag Sci 71:114-122. https://doi.org/10. $1002 / p s .3776$

Kearns CA, Inouye DW (1997) Pollinators, flowering plants, and conservation biology. Much remains to be learned about pollinators and plants. Bioscience v. 47:297-307. https://doi.org/10. 2307/1313191

Kerr JF, Wyllie AH, Currie AR (1972) Apoptosis: a basis biological phenomenon with wide-ranging implications in tissue kinetics. $\mathrm{Br}$ J Cancer 26:239-257. https://doi.org/10.1038/bjc.1972.33

Laurino D, Manino A, Patetta A, Porporato M (2013) Toxicity of neonicotinoid insecticides on different honey bee genotypes. Bull Insectology 66:119-126

Lenzi M, Orth AI, Laroca S (2003) Associação das abelhas silvestres (Hym., Apoidea) visitantes das flores de Schinus terebinthifolius (Anacardiaceae), na Ilha de Santa Catarina (sul do Brasil). Acta Biol Parana 32:107-127. https://doi.org/10.5380/abpr.v32i0.621

Loeffler M, Kroemer G (2000) The mitochondrion in cell death control: certainties and incognita. Exp Cell Res 256:19-26. https:// doi.org/10.1006/excr.2000.4833

Michener CD (1954) Bees of Panama. Bull Am Mus Nat Hist 104:1-176

Nicodemo D, Maioli MA, Medeiros HC, Guelfi M, Balieira KV, De Jong D, Mingatto FE (2014) Fipronil and imidacloprid reduce honeybee mitochondrial activity. Environ Toxicol Chem 33:2070-2075. https://doi.org/10.1002/etc.2655

Nogueira-Neto P (1997) Vida e criação de abelhas indígenas sem ferrão. Nogueirapis, São Paulo

OECD (1998) Guidelines for the testing of chemicals. Honeybee Acute Oral Toxicity Test, n. 213

Oliveira RA, Roat TC, Carvalho SM, Malaspina O (2014) Side-effects of thiamethoxam on the brain and midgut of the africanized honeybee Apis mellifera (Hymenopptera: Apidae). Environ Toxicol 29:1122-1133. https://doi.org/10.1002/tox.21842

Percival MS (1965) Floral Biology. Pergamon Press, London

Risau W (1997) Mechanisms of angiogenesis. Nature 386:671-674. https://doi.org/10.1038/386671a0

Rossi CA, Roat TC, Tavares DA, Cintra-Socolowski P, Malaspina O (2013) Brain morphophysiology of Africanized bee Apis mellifera exposed to sublethal doses of imidacloprid. Arch Environ Contam Toxicol 65:234-243. https://doi.org/10.1007/s00244013-9897-1

Rybak J et al. (2010) The digital bee brain: integrating and managing neurons in a common 3D reference system. Front Syst Neurosci 4. doi: https://doi.org/10.3389/fnsys.2010.00030

Sanchez-Bayo F, Goka K (2014) Pesticide residues and bees-a risk assessment. PLoS ONE 9:e94482. doi:https://doi.org/10.1371/ journal.pone.0094482

Silva-Zacarin ECM, Tomaino GA, Brocheto-Braga MR, Taboga SR, De Moraes RS (2007) Programmed cell death in the larval salivary glands of Apis mellifera (Hymenoptera, Apidae). J Biosci 32:309-328. https://doi.org/10.1016/j.micron.2006.12.001

Snodgrass RE (1956) Anatomy and physiology of the honeybees. Comstock Publishing Associates, New York, NY 
Suchail S, Debrauwer L, Belzunces LP (2004) Metabolism of imidacloprid in Apis mellifera. Pest Manag Sci 60:291-296. https://doi. org/10.1002/ps.772

Tautz J (2008) The buzz about bees: Biology of a superorganism. Springer-Verlag, Berlin

Wilhelmus MMM et al. (2006a) Specific association of small heat shock proteins with the pathological hallmarks of Alzheimer's disease brains. Neuropathol Appl Neurobiol 32:119-130. https:// doi.org/10.1111/j.1365-2990.2006.00689.x
Wilhelmus MMM et al. (2006b) Small heat shock protein HspB8: its distribution in Alzheimer's disease brains and its inhibition of amyloid- $\beta$ protein aggregation and cerebrovascular amyloid- $\beta$ toxicity. Acta Neuropathol 111:139-149. https://doi.org/10.1007/ s00401-005-0030-z

Wilms W, Wendel L, Zillikens A, Blochtein B, Engels W (1997) Bees and other insects recorded on flowering trees in a subtropical Araucaria forest in southern Brazil. Stud Neotrop Fauna E 32:220-226. https://doi.org/10.1080/01650521.1997.11432425 